\title{
Effect of Nephropathy on the Composition of Apolipoprotein- Containing Particles in NIDDM
}

\author{
Takashi Nagai $^{1}$, Takashi Tomizawa ${ }^{1}$, Katsuyuki Nakajima ${ }^{2}$, Yutaka Uehara ${ }^{3}$, and \\ Masatomo Mori $^{3}$ \\ ${ }^{1}$ Department of Internal Medicine, Public Tomioka General Hospital, Gunma, Japan \\ ${ }^{2}$ Japan Immunoresearch Laboratories, Gunma, Japan \\ ${ }^{3}$ The First Department of Internal Medicine, Gunma University School of Medicine, Gunma, Japan
}

\begin{abstract}
We investigated the effect of nephropathy on the composition of apolipoprotein-containing particles in non-obese NIDDM patients with normocholesterolemia. Sixty-seven normal control subjects (group A), 48 NIDDM patients without nephropathy (group B) and 36 NIDDM patients with nephropathy (group C) were studied. Apolipoprotein Al or B100 containing particles (Apo Al or Apo B100) were isolated by immunoaffinity columns prepared with monoclonal antibodies. The total cholesterol (CH), esterified cholesterol (EC) and free cholesterol (FC) content in these particles was analyzed. Both the EC/FC ratio levels in Apo $\mathrm{Al}$ and in Apo B100 in group C were significantly higher than those in group A or B. Both the $\mathrm{CH}$ in $\mathrm{Apo} \mathrm{Al} /$ apolipoprotein $\mathrm{Al}$ ratio and in Apo B100/apolipoprotein B100 ratio levels in group C were significantly lower than those in group A or B. The insulin resistance index showed significant positive correlation with the EC/FC ratio levels in Apo Al and in Apo B100, and showed significant negative correlation with the $\mathrm{CH}$ levels in Apo Al/apolipoprotein $\mathrm{Al}$ ratio and the $\mathrm{CH}$ levels in Apo B100/apolipoprotein B100 ratio levels in group C. Those compositional changes of lipoproteins in NIDDM patients with nephropathy may reflect partial insulin resistance and deteriorating atherosclerosis. J Atheroscler Thromb, 1998; 5 : 54-59.
\end{abstract}

Key words : Apolipoprotein Al, B100 particles, Urinary albumin excretion, Insulin resistance

\section{Introduction}

Lipid abnormalities such as hypertriglyceridemia, low levels of $\mathrm{HDL}$-cholesterol $(\mathrm{CH})$ and elevated $\mathrm{LDL}-\mathrm{CH}$ levels have been observed in patients with diabetic nephropathy $(1,2)$. Non-obese male patients with insulin resistance syndrome have significantly higher basal insulin and triglyceride levels and lower HDL-CH levels compared to controls (3). Previous studies have suggested that insulin resistance and albuminuria may be associated in NIDDM $(4,5)$, while lipid metabolism abnormalities other than quantitative changes in lipoproteins are

Address for correspondence: Takashi Nagai, The Department of Internal Medicine, Public Tomioka General Hospital, 2073-1 Tomioka, Tomioka, Gunma 370-2396 Japan

Received August 17, 1998.

Accepted for publication October 14, 1998. found in diabetic patients. An increased remnant lipoprotein, such as intermediate density lipoprotein (IDL) occurring in NIDDM even with normolipidemia patients (6), has been reported. However, the effect of nephropathy on serum lipid and lipoprotein composition in NIDDM patients with normocholesterolemia has been less frequently reported. In the present study, we analyzed apolipoprotein Al or B100 containing particles or remnantlike particles $(\operatorname{RLP})(7,8)$ isolated by immunoaffinity columns prepared with monoclonal antibodies in normal control subjects, non-obese NIDDM patients with or without nephropathy.

\section{Materials and Methods}

Subjects

This study involved 67 normal control male subjects 
(group A) and 84 non-obese male NIDDM patients (groups $B$ and $C$ ). All NIDDM patients were on a diabetic diet. In group $\mathrm{B}, 18$ patients were given an oral hypoglycemic drug (sulfonylurea). In 16 patients, insulin treatment (mean administration of insulin dose : $18.8 \pm 2.4$ units) was given for control of blood glucose. In group $\mathrm{C}, 13$ patients were given an oral hypoglycemic drug (sulfonylurea). In 12 patients, insulin treatment (mean administration of insulin dose: $16.8 \pm 2.8$ units) was given. In group $A$, all subjects had a urinary albumin excretion index (Alb-l) of less than $30 \mathrm{mg} / \mathrm{g}$ - creatinine. In 48 of the NIDDM patients, there was no diabetic retinopathy and each had an Alb-I of less than $30 \mathrm{mg} / \mathrm{g} \cdot$ creatinine (group B). In group $C$, all 36 NIDDM patients had diabetic retinopathy with Alb-I ranging from 200 to $600 \mathrm{mg} / \mathrm{g}$ • creatinine. In all 3 groups, body mass index (BMI) levels were less than $24.0 \mathrm{~kg} / \mathrm{m}^{2}$. Three groups were matched to controls by age. All fasting total $\mathrm{CH}$ levels were less than $5.7 \mathrm{mmol} / \mathrm{I}$ and all fasting triglyceride levels were less than 2.4 $\mathrm{mmol} / \mathrm{l}$. All urinary specimens showed negative for hematuria or urinary cast. All subjects showed normal ranges of hematology, liver function and electrolytes. All serum creatinine $(\mathrm{Cr})$ levels were within the normal range (less than $97 \mu \mathrm{mol} / \mathrm{l}$ ). All diabetic patients had been treated for a minimum of 12 months and their blood glucose had remained stable for at least 6 months. Antihypertensive drugs were given in group $B(n=13$, these patients were given angiotensin converting enzyme inhibitor, cilazapril [Eizai Co. Ltd., Tokyo] $1 \mathrm{mg}$ daily) and group $C(n=24$, nineteen patients were given cilazapril 1 $\mathrm{mg}$ daily, of the 5 patients were given $2 \mathrm{mg}$ daily). Those patients had been treated for high blood pressure over a minimum period of 12 months.

\section{Methods}

Measurement of total $\mathrm{CH}$, esterified $\mathrm{CH}$ or free $\mathrm{CH}$ content in apolipoprotein $\mathrm{Al}$ particles (Apo $\mathrm{Al}-\mathrm{CH}$, EC or $\mathrm{FC}$ ) or apolipoprotein B100 particles (Apo B100-CH, EC or $\mathrm{FC})$ or remnant-like particles containing $\mathrm{CH}$ values (RLP$\mathrm{CH})$ :

Five mg of anti-apolipoprotein $\mathrm{Al}(\mathrm{H}-12)$, anti-apolipoprotein $\mathrm{B} 100(\mathrm{JI}-\mathrm{H})$, or anti-apolipoprotein $\mathrm{Al}$ and antiapolipoprotein B100 monoclonal antibodies were coupled to $1 \mathrm{ml}$ of $\mathrm{CNBr}$-Sepharose 4B affinity column (Phamacia, Sweden) (7) according to the recommendations of the manufacturer. Any remaining active sites on the columns were blocked with $0.2 \mathrm{M}$ glycine. Before use, the columns were conditioned to reduce non-specific binding by 2 cycles of incubation with fetal calf serum for $1 \mathrm{hr}$ at room temperature with gentle shaking, followed by washing with $0.1 \mathrm{mM}$ acetic acid in $0.5 \mathrm{M} \mathrm{NaCl}$. Five $\mu \mathrm{l}$ of serum was added to $300 \mu \mathrm{l}$ of immunoaffinity column suspension which contained $25 \mu \mathrm{l}$ of apolipoprotein $\mathrm{Al}$ (125 $\mu \mathrm{g}$ of $\mathrm{IgG}$ ), $25 \mu \mathrm{l}$ apolipoprotein B100 (125 $\mu \mathrm{g}$ of IgG), or $25 \mu \mathrm{l}$ of apolipoprotein Al and apolipoprotein B100.
The reaction mixture was gently shaken for $60 \mathrm{~min}$ at room temperature to assure complete mixing. The bound fraction of $\mathrm{Apo} \mathrm{Al}-\mathrm{CH}$ and $\mathrm{Apo} \mathrm{B} 100-\mathrm{CH}$, and the unbound fraction of $\mathrm{RLP}-\mathrm{CH}$ were eluted from the mixed gels with $1.0 \mathrm{M}$ acetic acid. The fraction tubes were allowed to sit for $10 \mathrm{~min}$ and $30 \mu \mathrm{l}$ of the supernatant was taken to assay Apo $\mathrm{Al}-\mathrm{CH}, \mathrm{EC}$ and $\mathrm{Apo} \mathrm{B} 100-\mathrm{CH}, \mathrm{EC}$, and $\mathrm{RLP}-\mathrm{CH}$ with the Mercko test diagnostic kit (Kanto-kagaku, Tokyo). Apo Al-FC levels were calculated as Apo $\mathrm{Al}-\mathrm{CH}$ minus EC. Apo B100-FC levels were calculated as Apo $\mathrm{B} 100-\mathrm{CH}$ minus EC. The coefficient of variation of Apo Al-CH, EC or Apo B100-CH, EC or RLP-CH measurements were each less than $2.5 \%$.

Analysis of apolipoprotein, triglyceride, HDL-CH, LDL$\mathrm{CH}$ and insulin :

Apolipoprotein $\mathrm{Al}$ and $\mathrm{B} 100$ values were measured by turbidimetric immunoassay. Triglyceride values were measured by enzymatic determination. $\mathrm{HDL}-\mathrm{CH}$ was measured by precipitation and enzymatic determination. LDL-CH was calculated according to the method of Friedewald et al (9). Insulin was measured by a radioimmunoassay. An insulin resistance index was calculated as fasting blood glucose $(\mathrm{mmol} / \mathrm{l}) \times$ basal insulin $(\mu \mathrm{U} / \mathrm{ml}) /$ 22.5 (10).

\section{Renal function}

Cr was measured by Jaffe's rate assay. Urinary samples were collected from the first morning urine excretion. Urinary albumin was measured by radioimmunoassay. The Alb-I was calculated as urinary albumin/urinary $\mathrm{Cr}$ $(\mathrm{mg} / \mathrm{gCr})$.

\section{Statistical analysis}

Parameters are shown as mean \pm SEM. The data were analyzed by Duncan's multiple range test. Correlation between $\mathrm{Apo} \mathrm{Al}-\mathrm{CH}$ and $\mathrm{HDL}-\mathrm{CH}$, Apo $\mathrm{B} 100-\mathrm{CH}$ and $\mathrm{LDL}-\mathrm{CH}$, or basal insulin levels and other parameters in the 3 groups were determined by linear regression analysis. A level of $p<0.05$ was accepted as statistically significant.

\section{Results}

As shown in Table 1, fasting blood glucose, $\mathrm{HbA1c}$ and insulin resistance index levels in group $B$ or $C$ were significantly higher than in group A $(p<0.01)$. BMI, systolic blood pressure, diastolic blood pressure, basal insulin, serum $\mathrm{Cr}$ and total- $\mathrm{CH}$ levels showed no significant difference between the 3 groups. The Alb-I levels in group $C$ were significantly higher than in group $A$ or $B$ $(p<0.01)$.

$\mathrm{HDL}-\mathrm{CH}$ or $\mathrm{Apo} \mathrm{Al}-\mathrm{CH}$ levels in group $\mathrm{C}$ were significantly lower than in group $A$ or $B$ ( $C$ vs. $A: p<0.01, C$ vs. $\mathrm{B}: p<0.05)$. Apo $\mathrm{Al}-\mathrm{EC}$ or $\mathrm{FC}$ levels in group $\mathrm{C}$ were significantly lower than in group $A$ or $B(p<0.01)$. LDL$\mathrm{CH}$ or $\mathrm{Apo} \mathrm{B} 100-\mathrm{CH}$ levels in groups $\mathrm{B}$ and $\mathrm{C}$ were 
Nagai et al.

Table 1. Background data of subjects in various parameters

\begin{tabular}{|c|c|c|c|}
\hline & group A & group B & group C \\
\hline number & 67 & 48 & 36 \\
\hline age & $52.8 \pm 2.2$ & $58.4 \pm 4.6$ & $59.4 \pm 3.4$ \\
\hline duration (years) & & $5.1 \pm 0.5$ & $10.8 \pm 0.6^{\# \#}$ \\
\hline systolic blood pressure $(\mathrm{mmHg})$ & $128.2 \pm 3.7$ & $134.3 \pm 4.2$ & $139.1 \pm 4.3$ \\
\hline diastolic blood pressure $(\mathrm{mmHg})$ & $75.6 \pm 2.2$ & $78.2 \pm 2.2$ & $80.2 \pm 2.3$ \\
\hline $\mathrm{BMI}\left(\mathrm{kg} / \mathrm{m}^{2}\right)$ & $22.1 \pm 0.3$ & $22.3 \pm 0.3$ & $22.2 \pm 0.3$ \\
\hline FBG $(\mathrm{mmol} / \mathrm{l})$ & $5.08 \pm 0.07$ & $7.19 \pm 0.34^{* *}$ & $7.22 \pm 0.33^{* *}$ \\
\hline HbA1c $(\%)$ & $4.63 \pm 0.15$ & $7.12 \pm 0.28 * *$ & $7.14 \pm 0.29^{* *}$ \\
\hline basal insulin $(\mu \mathrm{U} / \mathrm{ml})$ & $5.1 \pm 0.5$ & $6.1 \pm 0.7$ & $7.2 \pm 1.1$ \\
\hline insulin resistance index & $1.15 \pm 0.15$ & $1.95 \pm 0.21^{* *}$ & $2.31 \pm 0.31^{* *}$ \\
\hline triglyceride $(\mathrm{mmol} / \mathrm{l})$ & $1.38 \pm 0.07$ & $1.45 \pm 0.08$ & $1.63 \pm 0.08^{*}$ \\
\hline creatinine $(\mu \mathrm{mol} / \mathrm{l})$ & $79.6 \pm 1.9$ & $79.3 \pm 1.5$ & $80.2 \pm 1.8$ \\
\hline Alb-I (mg/gCr) & $15.8 \pm 1.7$ & $14.3 \pm 1.8$ & $398.2 \pm 43.8^{* * \# \#}$ \\
\hline total $\mathrm{CH}(\mathrm{mmol} / \mathrm{l})$ & $4.93 \pm 0.07$ & $5.13 \pm 0.08$ & $5.13 \pm 0.09$ \\
\hline $\mathrm{HDL}-\mathrm{CH}(\mathrm{mmol} / \mathrm{l})$ & $1.59 \pm 0.07$ & $1.32 \pm 0.08$ & $1.14 \pm 0.11^{* * \#}$ \\
\hline ApoAl-CH $(\mathrm{mmol} / \mathrm{l})$ & $1.56 \pm 0.06$ & $1.29 \pm 0.08$ & $1.11 \pm 0.11^{* * \#}$ \\
\hline ApoAl-EC (mmol/l) & $1.16 \pm 0.06$ & $0.97 \pm 0.07$ & $0.86 \pm 0.07^{* *}$ \\
\hline ApoAl-FC (mmol/l) & $0.40 \pm 0.03$ & $0.32 \pm 0.03$ & $0.26 \pm 0.04^{* *}$ \\
\hline apolipoprotein $\mathrm{Al}(\mathrm{mg} / \mathrm{dl})$ & $123.8 \pm 3.4$ & $121.2 \pm 4.2$ & $118.1 \pm 3.5$ \\
\hline $\mathrm{LDL}-\mathrm{CH}(\mathrm{mmol} / \mathrm{l})$ & $3.06 \pm 0.07$ & $3.52 \pm 0.15^{*}$ & $3.66 \pm 0.21^{*}$ \\
\hline apoB100-CH (mmol/l) & $3.29 \pm 0.08$ & $3.71 \pm 0.16^{*}$ & $3.82 \pm 0.22 *$ \\
\hline apoB100-EC (mmol/l) & $2.20 \pm 0.07$ & $2.59 \pm 0.12^{* *}$ & $2.78 \pm 0.14^{* *}$ \\
\hline apoB100-FC $(\mathrm{mmol} / \mathrm{l})$ & $1.09 \pm 0.04$ & $1.11 \pm 0.05$ & $1.04 \pm 0.07$ \\
\hline apolipoprotein B100 (mg/dl) & $112.8 \pm 3.8$ & $134.1 \pm 6.9^{*}$ & $151.4 \pm 8.9^{* * \#}$ \\
\hline $\mathrm{RLP}-\mathrm{CH}(\mathrm{mmol} / \mathrm{l})$ & $0.07 \pm 0.01$ & $0.13 \pm 0.02 *$ & $0.19 \pm 0.03^{* * \#}$ \\
\hline
\end{tabular}

group A : control

group B : diabetic patients without nephropathy

group $C$ : diabetic patients with nephropathy

FBG : fasting blood glucose, Alb-I: urinary albumin excretion rate, $\mathrm{CH}$ : cholesterol, EC : esterified cholesterol, ApoAl-CH : apolipoprotein particles Al containing cholesterol, RLP-CH : remnant like particles containing cholesterol

${ }^{*} p<0.05$ (vs. group A)

${ }^{* *} p<0.01$ (vs. group $A$ )

${ }^{\sharp} p<0.05$ (vs. group $B$ )

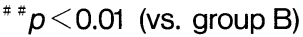

significantly higher than in group A $(p<0.05)$. Apo B100$E C$ levels in groups $B$ and $C$ were significantly higher than in group $A(p<0.01)$. Apolipoprotein B100 and RLP-CH levels in groups $B$ and $C$ increased significantly more than in group $A$ ( $B$ vs. $A: p<0.05, C$ vs. $A: p<0.01$ ). These levels in group $C$ increased significantly more than in group $B(p<0.05)$.

As shown in Fig. 1a and 1b, Apo Al-EC/FC ratio levels in group $C$ were significantly higher than in groups $A$ and $B$ $(p<0.01)$. Apo $B 100-E C / F C$ ratio levels in groups $B$ and $C$ were significantly higher than in group $A(p<0.01)$. The levels in group $C$ were significantly higher than in group $B$ $(p<0.01)$.

As shown in Fig. $2 \mathrm{a}$ and $2 \mathrm{~b}, \mathrm{Apo} \mathrm{Al}-\mathrm{CH} /$ apolipoprotein $\mathrm{Al}$ ratio and $\mathrm{Apo} \mathrm{B} 100-\mathrm{CH}$ /apolipoprotein $\mathrm{B} 100$ ratio levels in group $C$ were significantly lower than in groups $A$ or $B$ (C vs. $A: p<0.01, C$ vs. $B: p<0.05$ ).

As shown in Table 2, insulin resistance index levels showed significant positive correlation with $\mathrm{Apo} \mathrm{Al}-\mathrm{EC} /$ FC ratio levels in group $C(p<0.05)$ and Apo B100-EC/FC ratio levels in groups $A, B$ and $C(p<0.05)$. Insulin resistance index levels showed significant negative correlation with $\mathrm{Apo} \mathrm{Al}-\mathrm{CH}$ /apolipoprotein $\mathrm{Al}$ ratio levels in groups $\mathrm{B}$ and $\mathrm{C}(\boldsymbol{p}<0.05)$ and $\mathrm{Apo} \mathrm{B} 100-\mathrm{CH} /$ apolipoprotein $\mathrm{B} 100$ ratio levels in groups $A, B$ and $C(p<0.05)$.

While the correlation between $\mathrm{Apo} \mathrm{Al}-\mathrm{CH}$ and $\mathrm{HDL}-\mathrm{CH}$ was $0.584(p<0.01)$, the correlation between Apo B100$\mathrm{CH}$ and $\mathrm{LDL}-\mathrm{CH}$ was $0.786(p<0.01)$ for all subjects.

\section{Discussion}

The correlation between $\mathrm{Apo} \mathrm{Al}-\mathrm{CH}$ and $\mathrm{HDL}-\mathrm{CH}$ or Apo $\mathrm{B} 100-\mathrm{CH}$ and $\mathrm{LDL}-\mathrm{CH}$ was strongly significant. Therefore, the significantly lower $\mathrm{Apo} \mathrm{Al}-\mathrm{CH}$ levels and higher Apo B100-CH and apolipoprotein B100 levels shown in group $\mathrm{C}$ were compatible with previous reports 


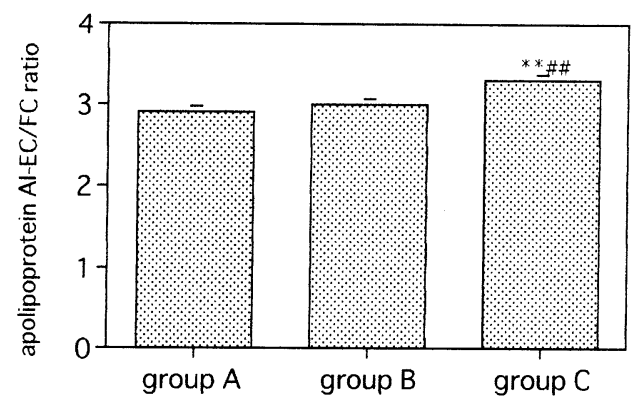

Fig. 1a. Esterified cholesterol (EC) to free cholesterol (FC) ratio in apolipoprotein $\mathrm{Al}$ containing particles (Apo $\mathrm{Al}$ ).

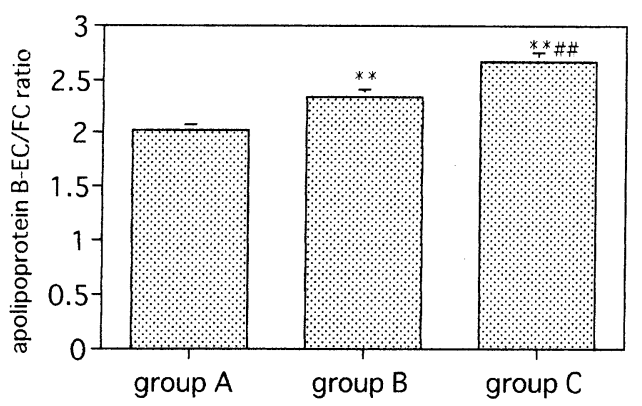

Fig. 1b. EC to FC ratio in apolipoprotein B100 containing particles (Apo B100).

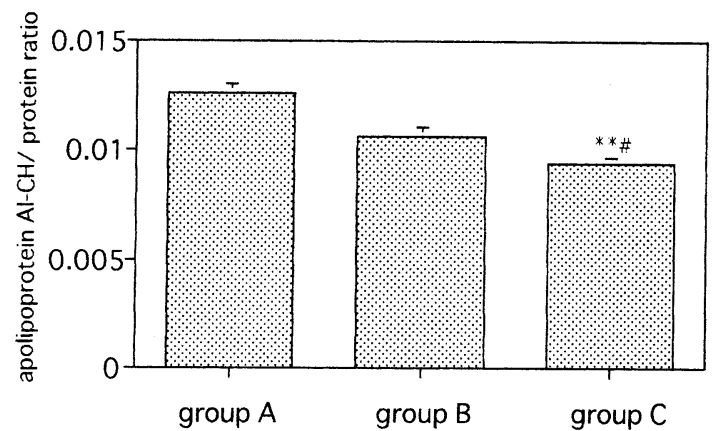

Fig. 2a. Total cholesterol (TC) in Apo Al to apolipoprotein Al ratio.

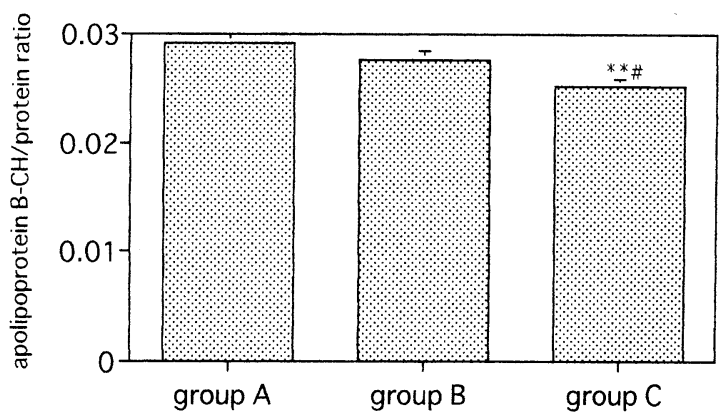

Fig. 2b. TC in Apo B100 to apolipoprotein B100 ratio. ** : $p<0.01$ (vs. group A), \#: $p<0.05$ (vs. group $\mathrm{B}$ ), \#\# : $p<$ 0.01 (vs. group B).

Table 2. Correlation between insulin resistance index and various parameters

\begin{tabular}{|c|c|c|c|}
\hline number & $\begin{array}{c}\text { group A } \\
\quad 67 \\
\end{array}$ & $\begin{array}{c}\text { group B } \\
48\end{array}$ & $\begin{array}{c}\text { group } C \\
36\end{array}$ \\
\hline systolic blood pressure $(\mathrm{mmHg})$ & $0.167(p=0.136)$ & $0.179(p=0.162)$ & $0.211 \quad(p=0.095)$ \\
\hline diastolic blood pressure $(\mathrm{mmHg})$ & $0.156(p=0.168)$ & $0.168(p=0.145)$ & $0.208(p=0.103)$ \\
\hline FBG $(\mathrm{mmol} / \mathrm{l})$ & $0.168(p=0.137)$ & $0.193(p=0.113)$ & $0.191(p=0.123)$ \\
\hline HbA1c (\%) & $0.189(p=0.098)$ & $0.216(p=0.092)$ & $0.198(p=0.109)$ \\
\hline triglyceride $(\mathrm{mmol} / \mathrm{l})$ & $0.189(p=0.098)$ & $0.209(p=0.098)$ & $0.212(p=0.098)$ \\
\hline creatinine $(\mu \mathrm{mol} / \mathrm{l})$ & $0.112(p=0.288)$ & $0.111(p=0.317)$ & $0.108(p=0.398)$ \\
\hline Alb-I (mg/gCr) & $0.192(p=0.095)$ & $0.194(p=0.111)$ & $0.192(p=0.121)$ \\
\hline total $\mathrm{CH}(\mathrm{mmol} / \mathrm{l})$ & $0.156(p=0.168)$ & $0.187(p=0.134)$ & $0.178(p=0.156)$ \\
\hline $\mathrm{HDL}-\mathrm{CH}(\mathrm{mmol} / \mathrm{l})$ & $-0.072(p=0.522)$ & $-0.077(p=0.494)$ & $-0.074(p=0.502)$ \\
\hline $\mathrm{ApoAI}-\mathrm{CH}(\mathrm{mmol} / \mathrm{l})$ & $-0.042(p=0.625)$ & $-0.037(p=0.784)$ & $-0.034(p=0.802)$ \\
\hline ApoAl-EC (mmol/l) & $-0.178(p=0.111)$ & $-0.194(p=0.111)$ & $-0.167(p=0.192)$ \\
\hline ApoAl-FC (mmol/l) & $-0.146(p=0.189)$ & $-0.145(p=0.208)$ & $-0.114(p=0.318)$ \\
\hline ApoAl-EC/FC ratio & $0.196(p=0.092)$ & $0.211 \quad(p=0.095)$ & $0.302\left(p=0.048^{*}\right)$ \\
\hline apolipoprotein $\mathrm{Al}(\mathrm{mg} / \mathrm{dl})$ & $0.085(p=0.321)$ & $0.089(p=0.386)$ & $0.078(p=0.423)$ \\
\hline ApoAl- $\mathrm{CH}$ /apolipoprotein $\mathrm{Al}$ ratio & $-0.228(p=0.069)$ & $-0.298\left(p=0.047^{*}\right)$ & $-0.311\left(p=0.045^{*}\right)$ \\
\hline $\mathrm{LDL}-\mathrm{CH}(\mathrm{mmol} / \mathrm{l})$ & $0.141(p=0.218)$ & $0.143(p=0.193)$ & $0.146(p=0.189)$ \\
\hline apoB100-CH $(\mathrm{mmol} / \mathrm{l})$ & $0.134(p=0.286)$ & $0.143(p=0.223)$ & $0.146(p=0.226)$ \\
\hline apoB100-EC (mmol/l) & $0.167(p=0.136)$ & $0.192(p=0.113)$ & $0.178(p=0.156)$ \\
\hline apoB100-FC (mmol/I) & $0.124(p=0.248)$ & $0.134(p=0.286)$ & $0.111(p=0.326)$ \\
\hline ApoB100-EC/FC ratio & $0.289\left(p=0.047^{*}\right)$ & $0.332\left(p=0.023^{*}\right)$ & $0.343\left(p=0.031^{*}\right)$ \\
\hline apolipoprotein B100 (mg/dl) & $0.176(p=0.118)$ & $0.198(p=0.108)$ & $0.199(p=0.107)$ \\
\hline ApoB100-CH/apolipoprotein $\mathrm{B} 100$ ratio & $-0.301\left(p=0.038^{*}\right)$ & $-0.321\left(p=0.038^{*}\right)$ & $-0.354\left(p=0.024^{*}\right)$ \\
\hline $\mathrm{RLP}-\mathrm{CH}(\mathrm{mmol} / \mathrm{l})$ & $0.201(p=0.081)$ & $0.211(p=0.097)$ & $0.231(p=0.092)$ \\
\hline
\end{tabular}

* : $p<0.05$ 
using HDL-CH or LDL-CH analysis (1, 2). Hyper apolipoprotein $\mathrm{B} 100$ and $\mathrm{LDL}-\mathrm{CH}$ levels predicted the development of albuminuria in diabetic patients (2), probably indicating deteriorating albuminuria in groups $\mathrm{B}$ and $\mathrm{C}$ in the future. RLP-CH levels in group $C$ were significantly higher than groups A and B. While RLP is an apolipoprotein $\mathrm{E}$-enriched fraction of triglyceride-rich lipoprotein, it reflects a chylomicron or VLDL remnant which is most likely to have originally been atherogenic particles $(7,8)$. Therefore, an increase of RLP-CH levels in diabetic patients with nephropathy may be one of the possible explanations for increased incidence of coronary heart disease (11).

Moreover, we analyzed EC and FC in Apo Al and Apo B100. There were significant increases in the Apo Al-

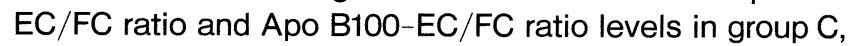
showing a relative increase of $E C$ content of $\mathrm{Apo} A \mathrm{Al}$ particles and Apo B100 particles in NIDDM patients with nephropathy. Moreover, the insulin resistance index showed significant positive correlation with Apo Al-EC/ FC ratio and Apo B100-EC/FC ratio levels in the NIDDM patients with nephropathy. The insulin resistance index is considered as a simple indicator of insulin resistance (10). Insulin resistance was present in groups B and C. Insulin resistance is also related to albuminuria in NIDDM patients $(4,5,12)$ and is associated with quantitative changes in lipoproteins (especially elevated triglyceride and decreased HDL-CH levels) (13), as well as being related to compositional changes in lipoproteins (low $\mathrm{LDL}-\mathrm{CH}$ /apolipoprotein $\mathrm{B}$ ratio) (14). Relative increased ApoAI-EC or Apo B100-EC levels reflecting compositional changes may be partially due to insulin resistance in NIDDM patients with nephropathy.

While glomerular lesions due to hyperlipidemia have been compared to atherosclerotic lesions and a similarity in their pathogenesis has been proposed (15), the glomerulosclerosis due to dietary supplementation with cholesterol increased the esterified cholesterol content in the kidney (16). Whether the difference of $\mathrm{CH}$ composition, particularly, a relative increase of EC content in apolipoprotein-containing particles probably due to insulin resistance increases atherogeneity or glomerulosclerosis, might be relevant. Moreover, whether or not cholesterol lowering therapy retards the progression of diabetic nephropathy (17) may be important.

A predominance of small dense $L D L-a$ decreased ratio of LDL-CH to plasma total apolipoprotein B-has been associated with an increased risk of heart disease (18). LDL size is significantly lower in diabetic subjects than in non-diabetic subjects (19). The presence of small dense LDL particles in NIDDM is also associated with insulin resistance (20), and a high prevalence of small dense LDL particles in NIDDM patients with nephropathy has been shown (21). Although we did not measure Apo Al or B100 particle size, both Apo $\mathrm{Al}-\mathrm{CH}$ /apolipoprotein $\mathrm{Al}$ ratio and $\mathrm{Apo} \mathrm{B} 100-\mathrm{CH} /$ apolipoprotein $\mathrm{B} 100$ ratio levels decreased significantly in group $C$. The insulin resistance index showed significant negative correlation with either ratio level in group $\mathrm{C}$. It may be relevant whether the decreased ratio of $\mathrm{Apo} \mathrm{Al}-\mathrm{CH} /$ apolipoprotein $\mathrm{Al}$ or $\mathrm{Apo}$ $\mathrm{B} 100-\mathrm{CH} /$ apolipoprotein $\mathrm{B} 100$ levels in NIDDM nephropathy cases is associated with insulin resistance or an increased risk of heart disease.

\section{References}

(1) Watts GF, Naumova R, Slavin BM, Morris RW, Houlston $R$, Kubal $C$, and Shaw KM : Serum lipids and lipoprotein in insulin-dependent diabetic patients with persistent microalbuminuria. Diabetic Med, 62 : 25-30, 1989

(2) Watts GF, Powrie JK, O'Brien SF, and Shaw KM: Apolipoprotein $B$ independently predicts progression of very-low-level albuminuria in insulin-dependent diabetes mellitus. Metabolism, 45: 1101-1107, 1996

(3) Swan JW, Walton C, Godsland IF, Crook D, Oliver MF, and Stevenson JC: Insulin resistance syndrome as a feature of cardiological syndrome $X$ in non-obese men. Br Heart J, 71: 41-44, 1994

(4) Niskanen $L$ and Laakso $M$ : Insulin resistance is related to albuminuria in patients with type II (non-insulindependent) diabetes mellitus. Metabolism, 42: 15411545,1993

(5) Nosadini R, Solini A, Velussi M, Muollo B, Francesco F, Sambataro M, Cipollina MR, Frausto de R, Brocco E, and Crepaldi G : Impaired insulin-induced glucose uptake by extrahepatic tissue is a hallmark of NIDDM patients who have or will develop hypertension and microalbuminuria. Diabetes, 43 : 491-499, 1994

(6) Kasama T, Yoshino G, Iwatani I, Hatanaka H, Kazumi T, Oimomi M, and Baba S: Increased cholesterol concentration in intermediate density lipoprotein fraction of normolipidemic non-insulin dependent diabetics. Atherosclerosis, 63 : 263-266, 1987

(7) Nakajima K, Saito T, Tamura A, Suzuki M, Nakano T, Adachi M, Tanaka A, Tada N, Nakamura H, Campos E, and Harvel RL: Cholesterol in remnant-like lipoproteins in human serum using monoclonal anti apo B-100 and anti apo A-I immunoaffinity mixed gels. Clin Chim Acta, 223: 53-71, 1993

(8) Campos E, Nakajima K, Tanaka A, and Harvel RL: Properties of an apolipoprotein enriched fraction of triglyceride-rich lipoproteins isolated from human blood plasma with a monoclonal antibody to apolipoprotein B100. J Lipid Res, 33: 369-380, 1992

(9) Friedewald WT, Levy R, and Fredrickson D: Estimation of concentration of LDL cholesterol without the use of preparative ultracentrifuge. Clin Chem, 18: 499-502, 1972

(10) Mattthews DR, Hosker JP, Rudenski AS, Naylor BA, Treacher DF, and Turner RC: Homeostasis model assessment : insulin resistance and $\beta$-cell function from fasting plasma glucose and insulin concentrations in man. Diabetologia, 28: 412-419, 1985

(11) Jensen T, Borch-Johnsen K, Kofoed-Enevoldsen A, and Deckert $T$ : Coronary heart disease in young type 1 (insulin-dependent) diabetic patients with and without diabetic nephropathy: incidence and risk factors. Diabetologia, 30 : 144-148, 1987 
(12) Nielsen S, Orekov H, Schmitz O, and Mogensen CE : Similar insulin sensitivity in NIDDM patients with normoand microalbuminuria. Diabetes Care, 18: 834-842, 1995

(13) Reaven GM: Role of insulin resistance in human disease. Diabetes, 37 : 1595-1607, 1988

(14) Mykkanen L, Kuusisto L, Haffner SM, Pyorala K, and Laakso $M$ : Hyperinsulinemia predicts multiple atherogenic changes in lipoproteins in elderly subjects. Arterioscler Thromb, 14 : 518-526, 1994

(15) Moorhead JF, Wheeler DC, and Varghese Z: Glomerular structures and lipids in progressive renal disease. Am J Med, $87: 12 \mathrm{~N}-20 \mathrm{~N}, 1989$

(16) Rayner HC, Ross-Gilbertson VL, and Walls J : The role of lipids in the pathogenesis of glomerulosclerosis in the rat following subtotal nephrectomy. Eur J Clin Invest, 20 :
97-104, 1990

(17) Lam KS, Cheng IK, Janus ED, and Pang RW: Cholesterol-lowering therapy may retard the progression of diabetic nephropathy. Diabetologia, 38: 604-609, 1995

(18) Krauss RM: Dense low density lipoproteins and coronary artery disease. Am J Cardiol, 75: 53B-57B, 1995

(19) Haffner SM, Paidi M, Mykkanen L, Howard BV, and Stern MP : Greater effect of diabetes on LDL size in women than in men. Diabetes Care, $17:$ 1164-1171, 1994

(20) Austin MA and Selby JV : LDL subclass phenotypes and the risk factors of the insulin resistance sydrome. Int Obes Relat Metab Disord, 19: S22-S26, 1995

(21) Hirano $T$, Naito $H$, Kurosawa $M$, Ebara $T$, Nagano $S$, Adachi M, and Yoshino $G$ : High prevalence of small LDL particles in non-insulin-dependent diabetic patients with nephropathy. Atherosclerosis, 123: 57-62, 1996 